\title{
$\begin{array}{ll}\text { Research Square } & \text { Preprints are preliminary reports that have not undergone peer review. } \\ \text { They should not be considered conclusive, used to inform clinical practice, }\end{array}$ or referenced by the media as validated information. \\ Current Ecological Status of Remote Coral Reefs of Clipperton Island, Tropical Eastern Pacific
}

\section{Claudia Pogoreutz}

King Abdullah University of Science and Technology

\section{Eric E. G. Clua}

PSL Research University: Universite PSL

JOSE DE JESUS ADOLFO TORTOLERO LANGARICA ( $\nabla$ adolfotortolero@hotmail.com )

Instituto de Ciencias del Mar y Limnología: Universidad Nacional Autonoma de Mexico Instituto de Ciencias del Mar y Limnologia https://orcid.org/0000-0001-8857-5789

\section{Research Article}

Keywords: Coral community, eastern Pacific, coral assemblage, trematodiasis infection, isolated coral reef

Posted Date: December 13th, 2021

DOI: https://doi.org/10.21203/rs.3.rs-1135884/v1

License: (c) (1) This work is licensed under a Creative Commons Attribution 4.0 International License. Read Full License 


\section{Abstract}

Clipperton, an uninhabited and remote coral atoll from the Eastern Pacific, is an important steppingstone area that harbors a high marine biodiversity. Despite its biogeographic importance, little information on the ecological status of its coral reefs is available from the last decade. Herein, we characterized the benthic coral community and health status among four different shallow reef-zones (North to South) of Clipperton during the Tara Pacific expedition in 2018. The benthic composition and coverage percentage, as well as occurrence of a pink-spotted coral phenotype (trematodiasis infection) was assessed. Total live coral cover on Clipperton reefs was 66\% (55-85\%), differing between sites, with massive Porites and branching Pocillopora corals dominating the benthic community with an average $48 \%$ (32-66\%), and $15 \%$ (3-21\%), respectively. While Clipperton reefs exhibited significant live coral cover overall, the trematode infection was commonly observed, with a higher occurrence in massive corals (Porites $27 \%$, and Pavona $31 \%)$. This observation is possibly related to the combined effects of previously heatwaves, and local inputs of guano-derived nutrients discharged during storms and hurricanes. These results demonstrates that even highly remote reefs supporting high coral cover can be subjected to local and global threats, including but not limited to parasite prevalence, likely in relation to natural disturbances such as thermal stress and tropical cyclones.

\section{Introduction}

Clipperton Island $\left(10^{\circ} 18^{\prime} \mathrm{N}, 109^{\circ} 13^{\prime} \mathrm{E}\right)$ constitutes a small uninhabited coral atoll located at the Western Edge of the Eastern Tropical Pacific (ETP) region (Robertson and Allen 1996). It lies about 1,100 km SW of the closest part of the American mainland and about $950 \mathrm{~km}$ off the nearest offshore islands, the Revillagegido Islands. Thereby, it constitutes one of the largest and most isolated coral reefs in the ETP (Robertson and Allen 1996), and also as an important biogeographic stepping stone for tropical biota, facilitating dispersal between the Eastern and Western Pacific regions (Robertson and Allen 1996; Romero-Torres et al. 2018; Boissin et al. 2019). On land, Clipperton hosts the largest breeding aggregation of masked booby and second largest aggregation of brown booby (Sula dactylatra and S. leucogaster). Under water, well-established fringing reefs with a relatively high diversity of reef-building scleractinian corals (18 species) have been documented (Glynn et al. 1996; Carricart-Ganivet and Reyes-Bonilla 1999). Yet, high live coral cover ranging from $10-100 \%$ between depths of $8-60 \mathrm{~m}$ (Glynn et al. 1996) along some $3.4 \mathrm{~km}$ of the atoll has been reported, which stands in contrast to the marginal patchy coral ecosystems situated closer to Continental America (Stuhldreier et al. 2015a,b). Global reports indicate partial to total mortality of the dominant reef-building coral genera Porites and Pocillopora for the entire Pacific region (Hughes et al. 2017, 2018; Eakin et al. 2019), including the ETP (Reyes-Bonilla and Calderón-Aguilera 1993; Reyes-Bonilla et al. 2002).

In the majority of observations on Clipperton Island, coral mortality has been mainly attributed to the El Niño Southern Oscillation (ENSO), high storm activity and long-period swells (Robertson and Allen 1996; Wang and Fiedler 2006). So far, reports of the ecosystem status suggest the land-seascape of Clipperton Island is healthy (Jost and Andréfouët 2006). Yet, no further studies have examined potential threat 
factors (e.g., diseases, bleaching and hurricane events) that may jeopardize the reef's health status. In this context, no data on the current benthic coral coverage and community status are available for Clipperton Island (Glynn et al. 1996; Jost and Andréfouët 2006; Wu et al. 2014).

In coral reef ecosystems, documentation of the structure and composition of key reef-building species communities provides critical baseline data to identify potential local stressors affecting the ecosystem (Hughes et al., 2018). While regular monitoring efforts may not be possible due to the remoteness of reef locations such as Clipperton Island, periodic monitoring of coral assemblages may help provide relevant insights to identify potential threats to coral reef functionality (Perry and Alvarez-Filip 2018). During a scientific sampling campaign as part of the Tara Pacific Expedition at Clipperton Island in August 2018, we assessed morpho-functional benthic community (i.e., reef-building species, non-reef building species, space-competitive algae and non-organic structures) abundance and composition, as well as the proportion of reef-building coral colonies that displayed signs of compromised health, specifically a pinkspotted phenotype that indicative of trematodiasis, an infection with parasitic trematodes. As Porites trematodiasis has recently been reported the most common disease in the Hawaiian Archipelago, occurring on over $60 \%$ of reefs in the region (Couch et al. 2014; Aeby 2016), we here provide a first assessment of pink spot incidence on the isolated and remote shallow reefs of Clipperton Island. The data presented on the status of reef benthic assemblage will be valuable for monitoring purposes and potential management recommendations to preserve the unique coral reef system of remote Clipperton Island.

\section{Materials And Methods}

\section{Study area and data collection}

The remote Clipperton Atoll in the tropical northeastern Pacific is situated 1,100 km from the nearest continental coast (Fig. 1) (Pitman et al. 2006; Robertson and Allen 1996). The island is of volcanic origin, and due to its $10 \mathrm{~km}^{2}$ extension and enclosed eutrophic inner lagoon considered an almost-atoll (Jost and Andréfouët 2006). The coral reef is composed by a $3.7 \mathrm{~km}^{2}$ well-developed fringing reef that is irregularly segmented by spurs and groves, reef terraces and seaward slopes dominated by massive Porites spp. and branching Pocillopora corals in shallower waters (1-15 m), and massive Porites, Pavona and Leptoseris corals in deeper waters (20-70 m) (Wellington et al. 1995; Glynn et al. 1996). The oceanographic environment is fairly stable in terms of the ambient sea water temperature (Glynn et al. 1996; Romero-Torres et al. 2020). Yet, episodic ENSO events have influenced the seascape of the Clipperton area, for instance intense swells and hurricanes occur during the tropical storm season from May to October (Wang and Fiedler 2006; Zhao and Raga 2015).

For benthic coral reef surveys, four different study sites were selected for each representative reef location around the atoll: North, South, East, and West of Clipperton Island's shallow reef zones (10-13 m water depth) (Fig. 1b). Benthic assessments were conducted on SCUBA using line intercept point (LIP) along three transects of $20 \mathrm{~m}$ length parallel to the shoreline. The LIP surveys used a weight suspended 
technique recording benthic data each $50 \mathrm{~cm}$ interval along the transect line (120 data points) for each site. The following benthic categories of morpho-functional groups were recorded: Corals: Pocillopora spp., Porites spp., Pavona spp., Leptoseris spp.; algae: macroalgae, crustose coralline algae (CCA); rubble (encompassing small not recently dead corals), rock, sand, and turf algae. Total live coral cover was calculated from the percentage sum product of all Pocillopora (branching), Porites (massive), Pavona (massive), Leptoseris (encrusting) corals for each site. In addition, the proportion of corals displaying signs of trematode infection (Podocotyloides stenometra), evident as pink spots on live tissue (Fig. 1) (Aeby, 2003) was recorded along with coral cover. Incidence of the trematode infection was recorded, i.e., all colonies displaying pink spots, regardless of whether infection was mild (few spots) or heavy (high densities of pink spots, covering $>50 \%$ of the colony).

As explanatory environmental variable, annual seawater temperature (SWT) from monthly data of the last decade (2008-2018) were acquired from satellite images of $4 \mathrm{~km}^{2}$ grid resolution (https://oceancolor.gsfc.nasa.gov), using type AquaModis ${ }^{\circledR}$ at level 3 , and analyzed with Wam_Statitist ${ }^{\circledR}$ ver. 6.33 software. To identified intensity of thermal-stress periods derived by El Niño South Oscillation (ENSO, warm "El Niño" and cold "La Niña" phases), the Ocean Niño Index 3.4 region was used (https://ggweather.com/enso/oni.htm/). We also recognized and categorized tropical cyclones that influenced Clipperton area, using data from the National Hurricane Center, NOAA (https://www.nhc.noaa.gov/data/) during past decade.

\section{Data analysis}

Multiple permutational analyses of variance (ANOVAs) and their respective post-hoc tests based on Euclidean matrices were used to evaluate differences in benthic morpho-functional group coverage and reef benthic composition (Shannon diversity, $\mathrm{H}^{\prime}$ ). Statistical significance of ANOVAs was tested with unrestricted permutations $(10,000)$ of raw data. For live coral cover, we performed one-way permutational Analysis of Variance (PERMANOVA) to test differences between reef zones (North, West, South, and East). and a principal coordinate analysis (PCOA) to determine coral composition resemblances at genus level among reef zones based on PERMANOVA's yields. All PERMANOVAs were conducted in PRIMER v.6 with PERMANOVA+ extension.

\section{Results}

Total live coral cover across the four sites surveyed averaged $66 \pm 7.7 \%$ (range 54-85\%), with statistically significant differences between reef zones (PERMANOVA; $F=3.6931, P=0.0002$ ) where evident for the North and the South reefs, with the highest live coral cover compared with the West and East reefs of the atoll (Fig. 2a and Table 1). No significant differences were found for diversity of benthic assemblages (Shannon diversity, $\mathrm{H}^{\prime}$ ) between reef zones (PERMANOVA; $\mathrm{F}=0.71818, P=0.6045$ ), revealing similar assemblage patterns for the entire Clipperton reef (Fig. 2 and Supplementary information). The benthic community was dominated by Porites spp. at all four reef sites (in total $~ 45 \%$ across all sites), followed by Pocillopora spp. ( 15\% across all sites). Rubble, algae, other life coral, rock, 
and CCA each individually contributed $5-10 \%$ of total benthic cover. Recently dead corals contributed $5 \%$ to total benthic cover, and were dominated by dead branching Pocillopora (Table 1). The PCO results showed that live coral cover on the North reef was dominated mainly by the massive corals Porites and Pavona ( 80\%), and at the rest of the sites, coral cover was dominated by Porites and Pocillopora ( 60\%) (Fig. 2).

Table 1

Mean benthic cover proportion (\% \pm SD of total) of each morpho-functional group, including proportion of pink-spotted corals (potentially reflecting prevalence of trematode infections) for all Clipperton Island reef zones

\begin{tabular}{|c|c|c|c|c|c|}
\hline \multirow[b]{2}{*}{ Benthic group } & \multicolumn{5}{|c|}{ Benthic cover (\% of total) } \\
\hline & North & South & East & West & All reefs \\
\hline Porites & $52.26 \pm 22.87$ & $23.19 \pm 6.49$ & $27.13 \pm 15.81$ & $25.63 \pm 1.65$ & $32.05 \pm 17.30$ \\
\hline Porites (PS) & $14.78 \pm 12.17$ & $16.54 \pm 5.27$ & $13.11 \pm 13.43$ & $7.40 \pm 6.50$ & $12.96 \pm 9.23$ \\
\hline Pavona & $5.81 \pm 5.79$ & $1.67 \pm 2.89$ & $4.17 \pm 5.20$ & - & $2.91 \pm 4.24$ \\
\hline Pavona (PS) & $9.88 \pm 8.56$ & - & $1.67 \pm 2.89$ & $0.81 \pm 1.41$ & $3.09 \pm 5.69$ \\
\hline Leptoseris & - & - & - & $1.67 \pm 2.89$ & $0.42 \pm 1.44$ \\
\hline Leptoseris (PS) & - & $0.81 \pm 1.41$ & - & - & $0.20 \pm 0.70$ \\
\hline Pocillopora & $2.48 \pm 2.50$ & $16.48 \pm 4.90$ & $20.69 \pm 4.01$ & $19.07 \pm 5.95$ & $14.68 \pm 8.45$ \\
\hline CCA & $1.65 \pm 1.43$ & $4.13 \pm 3.81$ & $10.77 \pm 5.83$ & $19.07 \pm 9.57$ & $8.90 \pm 8.69$ \\
\hline Macroalgae & - & $4.96 \pm 0.07$ & $18.29 \pm 11.62$ & $0.83 \pm 1.44$ & $6.02 \pm 9.14$ \\
\hline Dead coral & $3.33 \pm 5.77$ & - & $2.50 \pm 4.33$ & $1.65 \pm 1.43$ & $1.87 \pm 3.39$ \\
\hline Rock & $1.63 \pm 2.82$ & $13.23 \pm 3.86$ & $1.67 \pm 1.44$ & $4.94 \pm 4.28$ & $5.37 \pm 5.69$ \\
\hline Rubble & $7.38 \pm 6.41$ & $14.86 \pm 6.54$ & - & $16.44 \pm 9.75$ & $9.67 \pm 8.90$ \\
\hline Sand & $0.81 \pm 1.41$ & $2.46 \pm 2.44$ & - & $2.50 \pm 2.50$ & $1.44 \pm 1.96$ \\
\hline Turf & - & $1.67 \pm 1.44$ & - & - & $0.42 \pm 0.97$ \\
\hline
\end{tabular}

Prevalence of pink spots, i.e., infection with the parasitic trematode $P$. stenometra were apparent at all sites, with an average of 26 and $31 \%$ (range $21-38$ and $0-66 \%$ ) prevalence in Porites spp. and other massive corals (Pavona and Leptoseris), respectively (Fig. 2). No other discolorations suggesting other diseases were observed. While pink spots occasionally matched the presence of small vermetid snails growing in the coral, this was only observed for a minuscule proportion of pink spots observed (estimated $<5 \%$ of total observations; personal observation C.P.). Porites displaying pink spots were frequent along 
transects at all four sites, while other infected coral genera were observed only at the north and south reefs of the atoll (Fig. 2a, Table 1). Infection was heavy in an estimated more than $50 \%$ of the surveyed massive coral colonies, including large specimens ( $>1 \mathrm{~m}$ diameter). Despite the high proportion of trematode-infected coral, highest coral mortality was noted mainly for branching corals and minimal in massive corals with signs of recent macroalgae and coralline algae overgrowth.

Annual Sea water Temperature was $28.40 \pm 0.80^{\circ} \mathrm{C}$, the $2015-2016$ period had the highest values of SWT and corresponded with the strongest 2015-2016 El Niño warm event over the past 10-years (Supplementary material Table S1). Also, synergic events (ENSO + cyclones) occurred in the many year periods, a total of 10 hurricanes and 6 tropical storms influenced (in some cases two events per year) Clipperton Atoll area (Table 2).

Table 2

Historical data of tropical cyclones at Saffir-Simson scale, annual sea water temperature (SWT), and the intensity of ENSO periods (based on Oni index 3.4) from 2008 to 2018 at Clipperton Island

\begin{tabular}{|c|c|c|c|c|}
\hline Tropical cyclones & Category (Saffir-Simson) & $\begin{array}{l}\text { Temp } \\
\left({ }^{\circ} \mathrm{C}\right)\end{array}$ & ENSO intensity & Year \\
\hline Boris / Fausto & Tropical storm /Hurricane & $\begin{array}{l}28.5 \pm \\
0.90\end{array}$ & La Niña weak & 2008 \\
\hline Carlos & Tropical storm & $\begin{array}{l}28.5 \pm \\
0.80\end{array}$ & $\begin{array}{l}\text { El Niño } \\
\text { moderate }\end{array}$ & 2009 \\
\hline Celia & Hurricane 2 & $\begin{array}{l}28.0 \pm \\
0.80\end{array}$ & La Niña strong & 2010 \\
\hline $\begin{array}{l}\text { Jova /Eugene / } \\
\text { Kenneth }\end{array}$ & $\begin{array}{l}\text { Tropical storm /Hurricane 1/ } \\
\text { Hurricane } 1\end{array}$ & $\begin{array}{l}28.0 \pm \\
1.00\end{array}$ & $\begin{array}{l}\text { La Niña } \\
\text { moderate }\end{array}$ & 2011 \\
\hline Emilia & Hurricane 1 & $\begin{array}{l}28.2 \pm \\
0.60\end{array}$ & Neutral & 2012 \\
\hline Alvin & Tropical storm & $\begin{array}{l}28.3 \pm \\
0.80\end{array}$ & Neutral & 2013 \\
\hline $\begin{array}{l}\text { Amanda / Marie } \\
\text { /Vance }\end{array}$ & Hurricane 1 (all) & $\begin{array}{l}28.5 \pm \\
0.80\end{array}$ & La Niño weak & 2014 \\
\hline Blanca /Sandra & Hurricane 1/ Hurricane 2 & $\begin{array}{l}29.0 \pm \\
0.90\end{array}$ & $\begin{array}{l}\text { La Niño very } \\
\text { strong }\end{array}$ & 2015 \\
\hline Blas & Tropical storm & $\begin{array}{l}28.8 \pm \\
0.70\end{array}$ & La Niña weak & 2016 \\
\hline Fernanda & Tropical storm & $\begin{array}{l}28.5 \pm \\
0.80\end{array}$ & La Niña weak & 2017 \\
\hline Fabio / Sergio & Tropical storm / Tropical storm & $\begin{array}{l}28.2 \pm \\
0.80\end{array}$ & La Niño weak & 2018 \\
\hline
\end{tabular}


The benthic reef community composition of Clipperton Island is dominated by reef-building corals, and exhibits a higher live coral cover (in particular of the genera Porites and Pocillopora, exceeding $>60 \%$ ) compared with other localities along the ETP. This high coral cover suggests overall fair health of this unique coral reef (Wellington et al. 1996; Glynn and Ault 2000; Jost and Andréfouët 2006; Romero-Torres et al. 2020). Yet, in spite of the geographic isolation of Clipperton Island, Clipperton, an uninhabited and remote coral atoll from the Eastern Pacific, is an important steppingstone area that harbors a high marine biodiversity. Despite its biogeographic importance, little information on the status of its coral reefs is available from the last decade. Herein, we characterized the benthic coral community and health status among different shallow reef-zones (North to South) of Clipperton during the Tara Pacific expedition in 2018. The benthic composition (as percentage cover) as well as occurrence of trematodiasis infection was assessed. Total live coral cover on Clipperton reefs was 66\% (55-85\%), differing between sites, with massive Porites and branching Pocillopora corals dominating the benthic community with an average $48 \%(32-66 \%)$, and $15 \%(3-21 \%)$, respectively. While Clipperton reefs exhibited significant live coral cover overall, the trematode infection was commonly observed, with a higher occurrence in massive corals (Porites $27 \%$, and Pavona 31\%). This observation is possibly related to the combined effects of previously heatwaves, and local inputs of guano-derived nutrients discharged into the reefs during cyclones events. These results demonstrates that even highly remote reefs supporting high coral cover cane subjected to local threats, including but not limited to parasite prevalence, likely in relation to natural disturbances such as thermal stress and tropical cyclones.

Our data reveals that live coral cover of the benthic reef community of Clipperton Island exhibits a similar range of proportion (10-100\%) compared to what was reported two decades earlier (Glynn et al., 1996), and characterized by the dominance of only four reef-building coral genera. In addition, coral cover appears to have remained relatively stable, or potentially has rapidly recovered from mass coral mortality events previously reported for the ETP region (Glynn 2000; Hughes et al. 2017, 2018; Eakin et al. 2019; Romero-Torres et al. 2020). The composition of benthic morpho-functional groups remains homogenous around the entire atoll, yet differences between reef zones, evidencing steady changes in coral composition from branching to massive corals mainly in the shallow reef community (Fig. 2) (CabralTena et al. 2018; Romero-Torres et al. 2020). This observation may be explained due to different exposure to wave energy. The Southern and Eastern reef zones in particular are more protected and may act as shelter areas for branching coral species (i.e., Pocillopora), in contrast to North-Western zones, which are more fragmented in shallow depths where massive resistant species (i.e., Porites and Pavona) dominate (Figs. 1, 2b).

Clipperton Island coral assemblages are remarkable different to common ETP reefs due to its prevalence and high abundance of stress-tolerant massive corals over branching corals even on shallow reefs. This feature may be related to extensive loss of cover and poor recovery of Pocilloporidae after heat events (i.e., El Niño ENSO 1982-83, 1997-98 and 2015-16). These results may suggest that relatively coral diversity (dominated by massive forms) may be able to uphold reef formation and maintain the major geomorphologic features characteristic of an atoll. Yet, coral assemblages shifting from fast-complexgrowth to low-simpler-growth could alter and constrain certain ecological traits, such as rugosity and 
carbonate production, which will in turn inevitably affect ecosystem functionality (Glynn et al. 1996; Perry and Alvarez-Filip 2018; Cabral-Tena et al. 2020). Thus, implementation of active restoration of Pocillopora species is recommended as a conservation tool to mitigate the likely low functional redundancy of shallow Clipperton reef areas (Perry and Alvarez-Filip 2018).

A high prevalence of dead and partially dead Porites and Pocillopora at greater depth (18-20 m) previously reported by Glynn et al. (1996) was not apparent in this study, but coral mortality and extreme fragmentation of Pocillopora were evident (personal observation by the authors). This observation may be due to mechanical impacts of severe storms and hurricanes (Table 2) that frequently disturb the reef frames of branching corals in the shallower reef areas of Clipperton (Hutchings 1986; Zhao and Raga 2015). The intensive and increasingly frequent storm events (i.e., tropical cyclones and ENSO) is known to benefit other benthic reef groups (e.g., macroalgae, coralline algae and massive corals) less prone to fragmentation, and which compete for available open spaces to settle on the substrate (Sheppard et al. 2009).

For massive corals, partial mortality could be related to the prevalence of $P$. stenometra infection in Porites spp., as suggested by a high incidence of observations of pink spots and tissue lesions on corals off Clipperton Island (Fig. 2). Incidence of $P$. stenometra infection have previously been observed in Porites spp. throughout the Pacific, ranging from reefs off Hawaii to Guam, Papua New Guinea, Australia, and French Polynesia (Aeby 2003). Previous studies have reported that $P$. stenometra infection can have a negative effect on coral calcification rate, reducing growth rates up to $50 \%$, and increasing bioerosion and space-competition, eventually resulting in coral mortality (Aeby 1992; Trillobet and Gobulic 2011). Of note, Porites corals only constitute intermediate hosts of infection with $P$. stenometra. The final hosts are fish feeding on coral polyps, such as butterfly fish (Aeby 1992, 2003), which are characterized by a low diversity and abundance on Clipperton Island reefs (Robertson and Allen 1996). Therefore, little top-down control of trematode infection may occur, which could in part explain the high incidence of pink spots on coral. Parasite infection-acquisition could further be related to the interchange of eutrophic water produced by the phosphate-rich sediments of meromictic enclosed lagoon waters and guano-derived nutrients, which are commonly discharged into the reefs during intense storms and hurricanes (Bourrouilh-LeJan et al. 1985; Jost and Andréfouët 2006). This effect coincides with the observation of higher proportions of pink-spotted, i.e., trematode-infected coral colonies in the Northern and Eastern reefs (Fig. 2), which are closer to the inner lagoon entrances (narrowest carbonate barrier) of the atoll.

This study demonstrates that remote shallow oceanic Clipperton Island reefs sustain high live coral cover but may be subject to local threats such as parasite (trematode) prevalence and natural disturbances, such as thermal stress and storm events. Considering the pronounced effects of such stressors that may slowly erode the fitness of the reef community (as reflected in reduced coral growth and accretion of the reef framework, and/or reduced coral cover and community complexity), we recommend the establishment of standardized monitoring of coral disease incidence. Further, synergic effects of thermal stress and local stressors of corals should be investigated further for a better understanding of long-term dynamics of remote reef systems, natural species resilience and their potential implications (causes and 
consequences) in the maintenance of the Clipperton benthic coral reef community. Finally, we highlight the importance of establishing long-term coral reef monitoring based on the live coral cover, structure and composition of corals species and other biological and ecological indicators that may provide more extensive information that help develop conservation and management strategies to reduce reef stressors, and protect the endemism, dispersion hotspot, and the natural refuge of coral reef biodiversity that Clipperton provides to the ETP region.

\section{Declarations}

\section{Acknowledgements}

The authors and Tara Pacific consortium are grateful to the commitment of the people and the following institutions and sponsors who made this singular expedition possible: CNRS, CSM, PSL, KAUST, Genoscope/CEA, ANR-CORALGENE, France Genomique, agnès b., the Veolia Environment Foundation, Region Bretagne, Serge Ferrari, Billerudkorsnas, AmerisourceBergen Company, Lorient Agglomération, Oceans by Disney, the Prince Albert II de Monaco Foundation, L'Oreal, Biotherm, France Collectivites, Kankyo Station, Fonds Français pour l'Environnement Mondial (FFEM), Etienne Bourgois, UNESCO-IOC, the Tara Foundation teams and crew. Also thank the Haut Commissariat de la République en Polynésie française for permission to perform this research at Clipperton Atoll. We would particularly like to thank A. Pey, J. Lancelot and M. Hertau for diving assistance during benthic surveys and C. Wilkinson for language editing services.

\section{Funding}

This project has been supported in part through the Tara Pacific Expedition, France Genomique grant number ANR-10-INBS-09, and the Genoscope/CEA.

Conflict of interest The authors declare no conflict of interest.

Ethical approval No animal testing was performed during this study

Sampling and field studies All necessary permits for sampling and observational field studies have been obtained by the authors from the competent authorities and are mentioned in the acknowledgments, if applicable.

Data availability All data generated or analyzed during this study are included in this published article and its supplementary information files.

Author contributions $\mathrm{CP}$, EEGC conceived the study, collected data and writing (original draft). EEGC conceived the study, supervising and funding acquisition CP collected data. JJATL analyzed data and writing (original draft). All authors review, edits and approved the final version of this manuscript.

\section{References}


Aeby GS (2003) Corals in the genus Porites are susceptible to infection by a larval trematode. Coral Reefs 22:216. doi:10.1007/s00338-003-0310-9

Aeby GS (1992) The potential effect the ability of a coral intermediate host to regenerate has had on the evolution of its association with a marine parasite. Proc. 7th Int. Coral Reef Symp. pp. 809-815

Aeby GS (2015) Porites trematodiasis.. In: In: Woodley CM, Downs CA, Bruckner AW, Porter JW, Galloway SB (eds) Diseases of coral. John Wiley \& Sons, New York, NY, pp 387-390

Bourrouilh-LeJan FG, Carsin JL, Niaussat PM, Thommeret Y (1985) Sédimentation phosphatée actuelle dans le lagon confiné de l'île Clipperton. Datations, sédimentologie et géochimie. Sciences Géologiques Mém, Strasbourg 77:109-124.

Boissin E, Pogoreutz C, Pey A, Gravier-Bonnet N, Planes S (2019) Millepora platyphylla (Cnidaria, Hydrozoa) range extended back to the Eastern Pacific, thanks to a new record from Clipperton Atoll. Zootaxa 4668:599-600. https://doi.org/10.11646/zootaxa.4668.4.11

Cabral-Tena RA, López-Pérez A, Reyes-Bonilla H, Calderon-Aguilera LE, Norzagaray-López CO, RodríguezZaragoza FA, Cupul-Magaña A, Rodríguez-Troncoso AP, Ayala-Bocos A (2018) Calcification of coral assemblages in the eastern Pacific: Reshuffling calcification scenarios under climate change. Ecol Indic 95:726-734. https://doi.org/10.1016/j.ecolind.2018.08.021

Carricart-Ganivet JP, Reyes-Bonilla H (1999) New and previous records of Scleractinian corals from Clipperton Atoll, Eastern Pacific. Pac Sci 53:370-375

Couch CS, Garriques JD, Barnett C, Preskitt L, Cotton J Walsh W (2014) Spatial and temporal patterns of coral health and disease along leeward Hawai'i Island. Coral Reefs 33:693-704. DOI 10.1007/s00338014-1174-x

Eakin CM, Sweatman HPA, Brainard RE (2019) The 2014-2017 global-scale coral bleaching event: insights and impacts. https://doi.org/10.1007/s00338-019-01844-2. Coral Reef 1-7

Glynn PW, Ault JS (2000) A biogeographic analysis and review of the far eastern Pacific coral reef region. Coral Reefs 19:1-23. https://doi.org/10.1007/s003380050220

Glynn PW, Veron JEN, Wellington GM (1996) Clipperton Atoll (eastern Pacific): oceanography, geomorphology, reef-building coral ecology and biogeography. Coral Reefs 15:71-99. https://doi.org/10.1007/BF01771897

Glynn PW (2000) Effects of the 1997-98 El Niño Southern-oscillation on Eastern Pacific corals and coral reefs: An overview. Proc. 9th Int. Coral Reefs Symp. Bali, Indonesia 2: 169-1174

Hughes TP et al (2017) Coral reefs in the Anthropocene. Nature 546:82-90. https://doi.org/10.1038/nature22901 
Hughes TP, Kerry JT, Baird AH, Connolly SR, Dietzel A, Eakin CM, Heron SF, Hoey AS, Hoogenboom MO, Liu G, McWilliam MJ, Pears RJ, Pratchett MS, Skirving WJ, Stella JS, Torda G (2018) Global warming transforms coral reef assemblages. Nature 556:492-496. https://doi.org/10.1038/s41586-018-0041-2

Hughes TP, Kerry JT, Álvarez-Noriega M, Álvarez-Romero JG, Anderson KD, Baird AH, Babcock RC, Beger M, Bellwood DR, Berkelmans R et al (2017) Global warming and recurrent mass bleaching of corals. Nature 543:373-377. https://doi.org/10.1038/nature21707

Hutchings PA (1986) Biologial destruction of coral reefs. A review. Coral Reefs 4:239-252.

10.1007/BF00298083

Jost CH, Andréfouët S (2006) Long term natural and human perturbations and current status of Clipperton Atoll, a remote island of the Eastern Pacific, Pacific. Conserv Biol 12:207-218. https://doi.org/10.1071/PC060207

Perry CT, Alvarez-Filip L (2018) Changing geo-ecological functions of coral reefs in the Anthropocene. Funct Ecol 1-13. https://doi.org/10.1111/1365-2435.13247

Pitman RL, Ballance LT, Bost C (2006) Clipperton Island: Pig sty, rat hole and booby prize. Mar Ornithol 194:193-194

Reyes-Bonilla H, Calderón-Aguilera LE (1993) The 1987 coral reef bleaching at Cabo Pulmo reef, Gulf of California, México. Bull Mar Sci 52:832-837

Reyes-Bonilla H, Carriquiry J, Leyte-Morales G (2002) Cupul-Magaña AEffects of the El Niño-Southern Oscillation and the anti-El Niño event (1997-1999) on coral reefs of the western coast of México.Coral Reefs21:368-372. https://doi.org/10.1007/s00338-002-0255-4

Robertson DR, Allen GR (1996) Zoogeography of the Clipperton fish fauna.pdf. Coral Reefs 15:121-131. https://doi.org/10.1007/BF01771902

Romero-Torres M, Acosta A, Palacio-Castro AM, Treml EA, Zapata FA, Paz-García DA, Porter JW (2020) Coral reef resilience to thermal stress in the Eastern Tropical Pacific. Glob Change Biol 00:1-11. https://doi.org/10.1111/gcb.15126

Romero-Torres M, Treml EA, Acosta A, Paz-García DA (2018) The Eastern Tropical Pacific coral population connectivity and the role of the Eastern Pacific Barrier. Sci Rep 8:9354. https://doi.org/10.1038/s41598018-27644-2

Sheppard CRC, Davy SK, Pilling GM (2009) The Biology of Coral Reefs. Oxford University Press, Londres, p 333

Stuhldreier I, Sánchez-Noguera C, Roth F, Cortés J, Rixen T, Wild C (2015a) Upwelling Increases Net Primary Production of Corals and Reef-Wide Gross Primary Production Along the Pacific Coast of Costa 
Rica Upwelling Increases Net Primary Production of Corals and Reef-Wide Gross Primary Production Along the Pacific Coast of Costa. Front Mar Sci 2:113. https://doi.org/10.3389/fmars.2015.00113

Stuhldreier I, Sánchez-Noguera C, Roth F, Jiménez C, Rixen T, Cortés J, Wild C (2015b) Dynamics in benthic community composition and influencing factors in an upwelling-exposed coral reef on the Pacific coast of Costa Rica. PeerJ 3:e1434. .https://doi.org/10.7717/peerj.1434

Tribollet A, Golubic S (2011) Reef bioerosion: agents and processes. In: Coral Reefs: An Ecosystem in Transition (eds. Z. Dubisnky and N. Stambler). Springer, Dordrecht-Heidelberg-London-New York, pp. 435-449

Wang C, Fiedler PC (2006) ENSO variability in the eastern tropical Pacific: a review. Prog Oceanog 69:239-266. https://doi.org/10.1016/j.pocean.2006.03.004

Wellington GM, Glynn PW, Veron JEN (1995) Clipperton Island:a unique atoll in the eastern Pacific.Coral Reefs14:162. https://doi.org/10.1007/BF00367234

Wu HC, Moreau M, Linsley BK, Schrag DP, Corrège T (2014)Investigation of sea surface temperature changes from replicated coral $\mathrm{Sr} / \mathrm{Ca}$ variations in the eastern equatorial Pacific (Clipperton Atoll) since 1874.Palaeogeog Palaeoclimat Palaeoecol412:208-222. https://doi.org/10.1016/j.palaeo.2014.07.039

Zhao H, Raga BG (2015) On the distinct interannual variability of tropical cyclone activity over the eastern North Pacific. Atmósfera 28:161-178. https://doi.org/10.20937/ATM.2015.28.03.02

\section{Figures}

\section{Figure 1}

Description of the study region and sites and coral phenotype. (a) The location of the isolated Clipperton Island in the Eastern Tropical Pacific $\neg$ and (b) detailed map of the study sites. Maps adapted from van Soest et al. (2011). (c)-(f) Representative observations of massive Porites corals off Clipperton Island in the Eastern Tropical Pacific exhibiting trematode infection (pink spots). Close-up (c) and overview (d-f) of Porites coral colonies displaying pink-spotted phenotypes. Side lengths of quadrat in (b) $0.25 \mathrm{~m}$, and $0.5 \mathrm{~m}$ in $(a, c, d)$. White arrows show pink-spotted areas on affected colonies 
a)

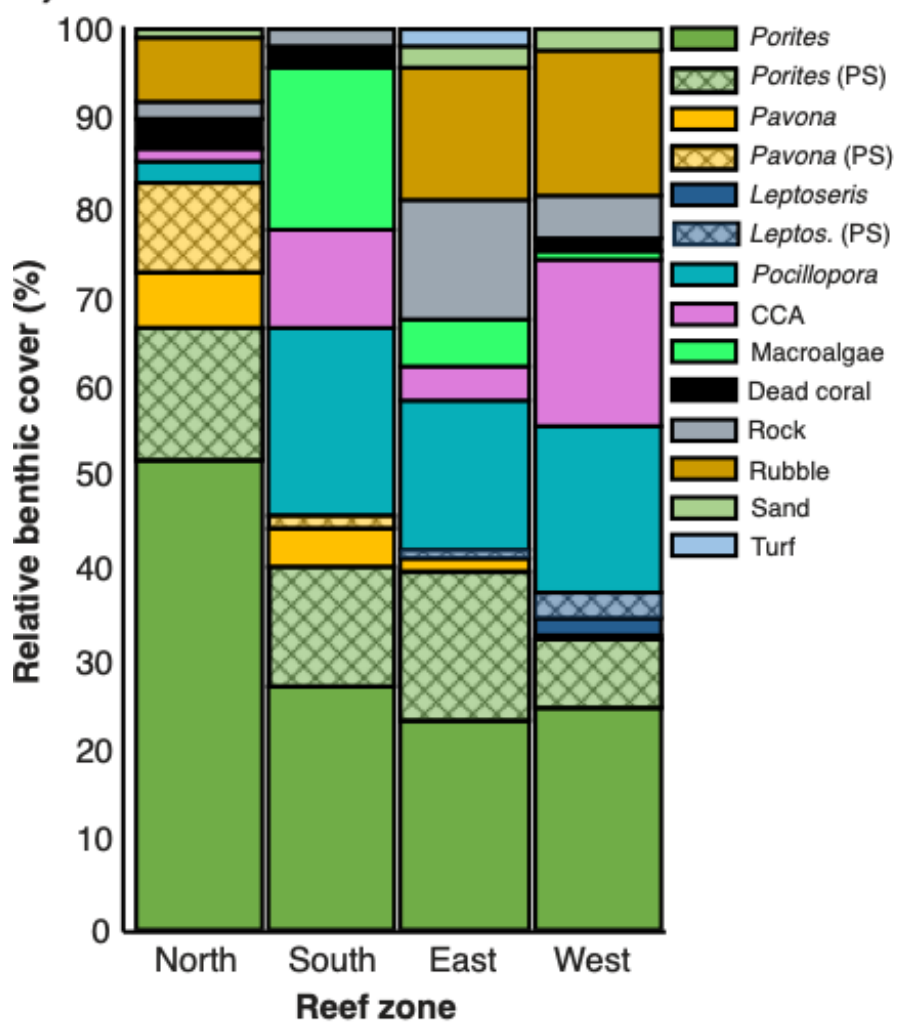

b)

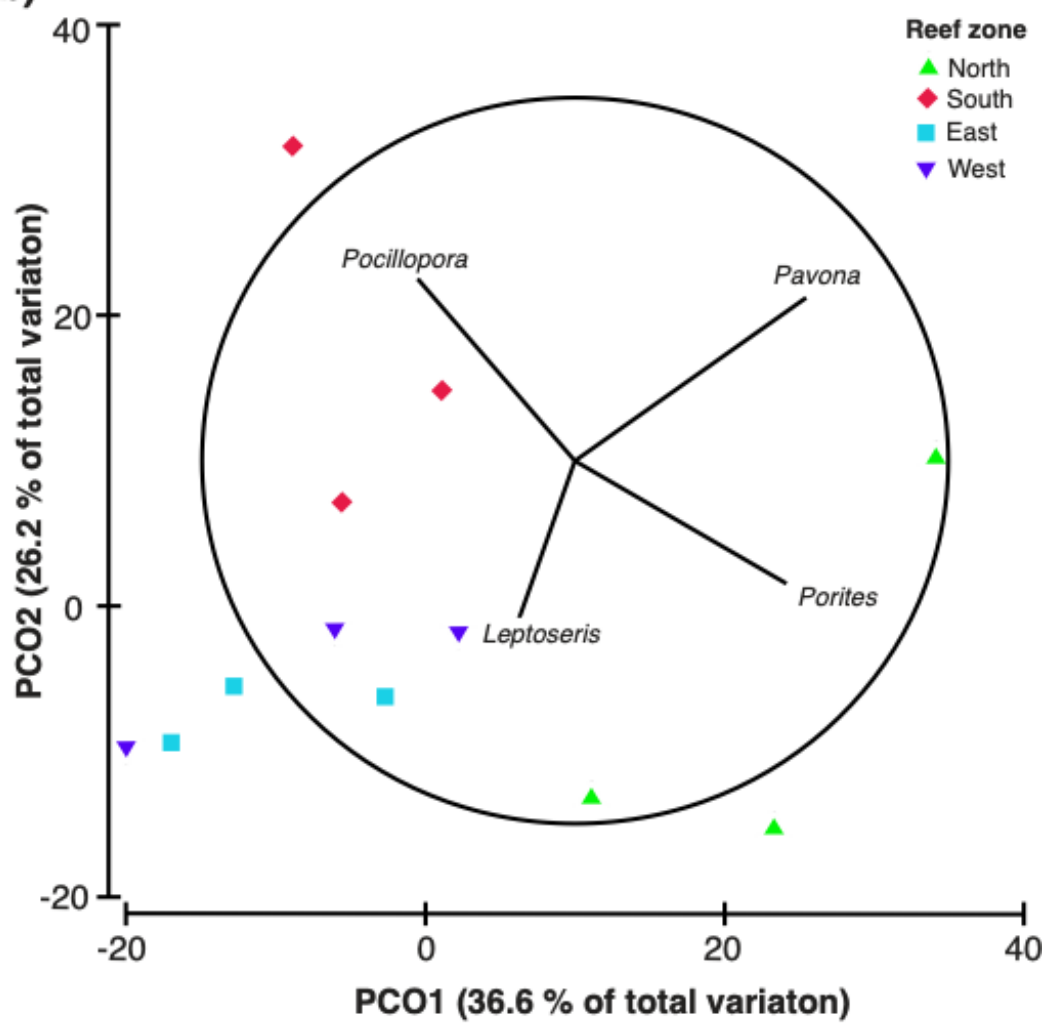

\section{Figure 2}

Characterization of benthic communities of four reef zones off the remote Clipperton Island in the Eastern Tropical Pacific. (a) Percentage cover of benthic morpho-functional groups (solid colors) and the proportion of infested corals displaying a pink-spotted phenotype (grid areas) for each reef zone. (b) Ordination plot (PCoA; \% of total variation explained) of benthic communities and the relationship with coral species on shallow reefs off Clipperton Island in the Eastern Tropical Pacific. CCA = Crustose coralline algae; $\mathrm{PS}=$ pink-spotted phenotype 